Penelitian

\title{
Ragam Jenis dan Aktivitas Mengisap Darah Lalat Stomoxys spp di Peternakan Sapi Perah di Kabupaten Bogor
}

\author{
(The Diversity and Blood Sucking Activity of Stomoxys spp Flies \\ in Dairy Cattle Farm in Bogor District) \\ Wendi Afriyanda ${ }^{1,2}$, Upik Kesumawati Hadi ${ }^{3}$, Susi Soviana ${ }^{3}$ \\ ${ }^{1}$ Mahasiswa Pascasarjana, Institut Pertanian Bogor \\ ${ }^{2}$ Program Studi Parasitologi dan Entomologi Kesehatan, Sekolah Pascasarjana, Institut Pertanian Bogor, Bogor \\ ${ }^{3}$ Divisi Parasitologi dan Entomologi Kesehatan, Institut Pertanian Bogor \\ *Penulis untuk korespondensi: wafriyanda@yahoo.com \\ Diterima 11 Januari 2018, Disetujui 7 Juni 2018
}

\begin{abstract}
ABSTRAK
Keberadaan Stomoxys spp (lalat kandang) pada peternakan sapi perah memiliki dampak negatif seperti penurunan produktivitas susu dan bobot badan, dan sebagai vektor penularan patogen penyakit. Penelitian ini bertujuan untuk mengetahui keanekaragaman jenis dan aktivitas mengisap darah lalat kandang. Lalat dikoleksi dengan menggunakan vavoa trap yang ditempatkan di luar peternakan sapi perah dan juga dilakukan pengamatan aktivitas mengisap darah lalat pada tubuh sapi selama 12 jam (06.00-18.00). Hasil penelitian menunjukkan bahwa ada empat spesies dari genus Stomoxys, yaitu, Stomoxys calcitrans (90.5\%), S. sitiens $(5,05 \%)$, S. indicus $(3,57 \%)$, dan S. bengalensis ( $0,88 \%)$. Aktivitas mengisap darah lalat Stomoxys spp sangat berfluktuasi di setiap jam pengamatan, mulai pukul 06.00-07.00 WIB, kemudian meningkat pada setiap jam, dan puncak aktivitas mengisap darah pada pukul 15.00-16.00 WIB. Hasil uji korelasi Pearson antara curah hujan dan aktivitas mengisap darah Stomoxys spp menunjukkan korelasi yang tinggi, tetapi tidak signifikan (R-0,922 dan nilai $p=0,253>0,05)$ karena waktu penelitian tidak lama.
\end{abstract}

Kata kunci: mengisap darah, lalat kandang, vavoa traps

\begin{abstract}
The existence of Stomoxys spp (stable flies) in dairy farms has negative impacts such as decreasing of milk productivity and body weight, beside of as a vector of pathogen transmission. This research aims to determine the diversity and blood sucking activity of stable flies. The flies were collected by using vavoa traps placed outside the dairy farm and also observed the blood sucking activities of the flies on the cows bodies for 12 hours $(06.00 \mathrm{am}-06.00 \mathrm{pm})$. The result showed that there were four specieses of Stomoxys genera, i.e., Stomoxys calcitrans (90,5\%), S. sitiens (5,05\%), S. indicus (3,57\%), and S. bengalensis (0,88\%). The blood sucking activities of Stomoxys spp were very fluctuated in each hour of observation, starting from 06.00-07.00 am, then increased on each hour, and peak of blood sucking activity at 15.00-16.00 pm. The result of Pearson correlation test between rainfall and blood sucking activity of Stomoxys spp showed a high correlation but unsignificant ( $R-0,922$ and value $p=0,253>0,05)$ because of the short duration of research.
\end{abstract}

Keywords: Blood sucking, stable flies, vavoa traps 


\section{PENDAHULUAN}

Ternak ruminansia mempunyai peranan dan arti penting bagi kehidupan petani di Indonesia. Kemampuan ternak untuk mengubah dan memanfaatkan hijauan, sisa-sisa hasil tanaman pangan, dan rumput alami menjadi produk peternakan bernilai gizi tinggi (daging dan susu) dan memberikan perubahan ekonomi yang nyata bagi para petani (Tarmudji, 2003).

Lalat kandang merupakan subfamili Stomoxyinae dari famili Muscidae (Diptera). Diantara 18 spesies Stomoxys yang ada, enam spesies tercatat dari Thailand, dan salah satunya adalah S. calcitrans yang berdistribusi kosmopolit. Lalat ini merupakan serangga pengganggu yang menyerang ternak, satwa liar, dan kadang-kadang juga manusia. Lalat ini, baik jantan dan betina yang dewasa, sama-sama pengisap darah dan menyebabkan gigitan yang menyakitkan serta menyebabkan kehilangan darah yang signifikan pada beberapa hewan. Pada populasi yang tinggi terjadi aktivitas menggigit yang tinggi, yang berakibat pada penurunan produktivitas hewan dan mengganggu kegiatan makan sehingga mengurangi bobot badan ternak dan berdampak pada produksi susu ternak tersebut (Phasuk et al., 2013; Taylor et al., 2012; Batista et al., 2005).

Stomoxys juga berperan dalam penularan penyakit Surra. Sukanto et al. (2000) melaporkan di Kabupaten Sumbawa, penyakit surra yang disebabkan oleh Trypanosoma evansi digolongkan dalam penyakit strategis yang menimbulkan kerugian ekonomi yang cukup besar. Lalat ini juga bertindak sebagai vektor bagi berbagai macam agen penyakit pada manusia dan hewan, seperti bakteri (Escherichia coli), protozoa (Besnoitia besnoiti), virus (Capripoxvirus), dan larva cacing yang infektif (Castro et al., 2007). Beragam spesies lalat telah diketahui sebagai vektor mekanik T. evansi, yaitu lalat-lalat dari genus Tabanus dan Stomoxys (Rodriguez et al., 2014; Sumba et al., 1998). Lalat ini aktif mengisap darah pada siang hari dan populasi lalat ini akan meningkat pada musim panas dan musim hujan. Menurut Phasuk et al. (2013), peningkatan populasi lalat ini terjadi pada bulan April sampai Juli pada saat musim panas dan terjadi fluktuasi yang berbeda pada bulan September sampai dengan Desember pada saat musim hujan, dan puncak tertinggi populasi lalat ini terjadi antara pukul 13.00-15.00 pada musim panas dan pukul 15.00-17.00 pada musim hujan. Untuk mengontrol populasi lalat kandang dan mengurangi dampak penularan penyakit dan ekonomi, beberapa pene- litian telah dilakukan untuk mempelajari spesies di lapangan dan di laboratorium. Pengendalian yang memadai memerlukan pengetahuan yang mendalam tentang biologi dan ekologi lalat kandang (Gilles et al., 2005).

Mengingat lalat kandang merupakan vektor dalam penularan penyakit pada hewan ternak maka peningkatan populasi lalat kandang dapat mempercepat penularan penyakit-penyakit tersebut. Selain sebagai serangga pengganggu, gigitan lalat kandang juga akan mengakibatkan ternak menjadi gelisah sehingga membuat produksi daging dan susu akan menurun serta akan berdampak pada pendapatan ekonomi para peternak. Permasalahan yang terjadi saat ini adalah belum adanya penelitian tentang aktivitas mengisap darah serta fluktuasi populasi lalat kandang di Indonesia sehingga pengendalian populasi lalat kandang tersebut belum terlaksanakan secara maksimal.

Penelitian ini bertujuan untuk mengetahui ragam jenis lalat Stomoxys spp di tujuh peternakan sapi perah di Kabupaten Bogor, untuk mengetahui aktivitas mengisap darah lalat Stomoxys spp pada setiap peternakan dan untuk mengetahui hubungan aktivitas mengisap darah lalat Stomoxys spp dengan faktor cuaca. Penelitian ini diharapkan dapat memberikan informasi secara mendalam mengenai perilaku mengisap darah lalat kandang pada ternak sapi perah dan fluktuasi populasi lalat kandang. Informasi ini diharapkan akan bermanfaat dalam menentukan strategi pengendalian lalat kandang.

\section{BAHAN DAN METODE}

\section{Waktu dan Tempat Penelitian}

Penelitian ini dilakukan di tujuh peternakan sapi perah yang ada di Kabupaten Bogor selama tiga bulan. Lokasi pengambilan sampel dipilih berdasarkan hasil survei keberadaan lalat $S$. calcitrans. Identifikasi lalat dan pengukuran aktivitas mengisap darah lalat dilakukan di Laboratorium Entomologi Kesehatan, Departemen Ilmu Penyakit Hewan dan Kesehatan Masyarakat Veteriner (IPHK), Fakultas Kedokteran Hewan, Institut Pertanian Bogor (FKH-IPB).

\section{Koleksi Sampel Lalat dan Identifikasi}

Pengambilan sampel lalat dilakukan menggunakan metode Changbunjong et al. (2012) dan Masmeathathip et al. (2006) di Thailand dengan cara memasang Vavoua traps yang terbuat dari kain katun biru dan hitam dan diletakkan di luar kandang 
dan dilakukan pengamatan setiap jam selama 12 jam mulai dari pukul 06.00-18.00. Lalat dikumpulkan pada setiap jam, dimatikan dengan menggunakan klorofom, dan selanjutnya dipinning. Pengumpulan sampel dilakukan sekali dalam sebulan di setiap lokasi peternakan dengan tiga kali pengulangan dari tujuh lokasi peternakan yang berbeda. Lalat yang telah terkumpul dibawa ke Laboratorium Entomologi Kesehatan, Fakultas Kedokteran Hewan, Institut Pertanian Bogor dan diidentifikasi dengan kunci identifikasi lalat menurut Tumrasvin dan Shinonaga (1978).

\section{Pengukuran Aktivitas Mengisap Darah Lalat Stomoxys Spp}

Pengukuran aktivitas mengisap darah lalat Stomoxys spp dilakukan dengan cara menghitung jumlah lalat yang hinggap pada tubuh sapi dengan menggunakan counter pada setiap peternakan dengan mengambil lima ekor sapi sebagai sampel. Penghitungan dilakukan selama lima menit pada setiap sapi dan akan diulang pada setiap jam selama 12 jam mulai dari pukul 06.00-18.00.

\section{Analisis Data}

\section{Keragaman jenis}

Analisis data keragaman jenis dilakukan secara deskriptif untuk melihat variabel yang telah ditetapkan sebagai berikut :

Kelimpahan nisbi $=$

\section{$\sum$ Individu spesies tertentu yang tertangkap}

Etotal individu yang tertangkap $\times 100 \%$

Frekuensi spesies $=$

\section{$\sum$ tertangkapnya spesies tertentu}

\section{$\sum$ jam penangkapan}

Dominasi spesies $=$ kelimpahan nisbi $\mathrm{x}$ frekuensi spesies

\section{Pengukuran aktivitas mengisap darah}

Pengukuran aktivitas mengisap darah lalat Stomoxys spp dilakukan dengan menghitung jumlah lalat yang hinggap pada tubuh sapi setiap jam dengan menggunakan counter dan dikonversi dalam bentuk grafik.

\section{Hubungan Curah Hujan dengan Jumlah Infestasi Lalat Kandang}

Data curah hujan selama tiga bulan (April-Juni 2015) dihubungkan dengan aktivitas mengisap darah lalat kandang dan dianalisis dengan menggunakan uji korelasi menggunakan komputer SPSS versi 16.0. Indeks curah hujan dihitung dengan menggunakan rumus sebagai berikut :

\section{$\mathrm{ICH}=\frac{\sum \text { curah hujan perbulanx } \sum \text { hari hujan perbulan }}{\sum \text { hari (dalam satu bulan) }}$}

\section{HASIL}

Sebanyak empat jenis spesies lalat kandang yang didapat pada penangkapan dengan menggunakan vavoa trap, yaitu Stomoxys calcitrans (913), S. sitiens (51), S. indicus (36), dan S. bengalensis (11) ( Tabel 1 dan Tabel 2). Aktivitas mengisap darah lalat Stomoxys spp dengan waktu yang sama pada setiap bulannya disajikan pada Gambar 1. Lalat Stomoxys spp aktif mengisap darah sepanjang hari, yang terlihat dengan selalu terdapatnya jumlah lalat yang sangat tinggi pada setiap jam pengamatan. Aktivitas lalat Stomoxys spp mulai diamati pada pagi hari pada pukul 06.00-07.00 dengan jumlah lalat yang hinggap di tubuh sapi sebanyak 95.91 lalat per bulan per peternakan dan semakin meningkat pada jam selanjutnya hingga mencapai puncak aktivitas pada pukul 15.00-16.00 dengan jumlah lalat 144 lalat per bulan per peternakan.

Hasil uji korelasi statistik menunjukkan adanya korelasi yang sangat kuat tetapi tidak signifikan ( $R=$ $0,922$ dan nilai $p=0,253)$ dengan arah korelasi yang tidak searah.

\section{PEMBAHASAN}

Ragam jenis lalat Stomoxys spp yang dijumpai pada setiap lokasi peternakan memiliki jenis spesies yang sama, tetapi keempat spesies tersebut tidak selalu ditemukan pada setiap peternakan. Lalat yang tertangkap semuanya termasuk ke dalam famili Muscidae dan masuk ke dalam genus Stomoxys. S. calcitrans merupakan spesies terbanyak yang dijumpai pada tujuh peternakan dengan jumlah terendah $82,44 \%$ dan jumlah tertinggi $93,75 \%$. S. indicus juga ditemukan pada setiap peternakan, tetapi jumlah $S$. indicus jauh lebih sedikit dibandingkan dengan S. calcitrnas (2,27\%-9,09\%,), sedangkan S. sitiens hanya ditemukan pada enam peternakan $(2,77 \%-8,39 \%)$, dan S. Bengalensis merupakan spesies 
40 | Afriyanda et al.

Tabel 1 Jenis spesies lalat kandang yang ditemukan di tujuh peternakan sapi perah di Kabupaten Bogor pada periode April-Juni 2015

\begin{tabular}{|c|c|c|c|c|c|}
\hline No & Peternakan & Titik Koordinat & Jenis Lalat & Jumlah & $\%$ \\
\hline \multirow{3}{*}{1} & \multirow{3}{*}{ Baru Sirem } & S 642.435 & S. calcitrans & 50 & 92,59 \\
\hline & & E 10657.003 & S. bengalensis & 2 & 3,70 \\
\hline & & & S. indicus & 2 & 3,70 \\
\hline \multirow{4}{*}{2} & \multirow{4}{*}{ Jaya Mandiri } & S 638.595 & S. calcitrans & 123 & 93,18 \\
\hline & & E 10653.713 & S. sitiens & 6 & 4,54 \\
\hline & & & S. indicus & 3 & 2,27 \\
\hline & & S 641.900 & S. calcitrans & 109 & 82,57 \\
\hline \multirow{3}{*}{3} & \multirow{3}{*}{ Baru Tegal } & E 10656.936 & S. sitiens & 8 & 6,06 \\
\hline & & & S. indicus & 12 & 9,09 \\
\hline & & & S. bengalensis & 3 & 2,27 \\
\hline \multirow{4}{*}{4} & \multirow{4}{*}{ Mekar Jaya } & S 638.636 & S. calcitrans & 177 & 89,39 \\
\hline & & E 10653.714 & S. sitiens & 12 & 6,06 \\
\hline & & & S. indicus & 7 & 3,53 \\
\hline & & & S. bengalensis & 2 & 1,01 \\
\hline \multirow{4}{*}{5} & \multirow{4}{*}{ Tegal Mandiri } & S 641.953 & S. calcitrans & 108 & 82,44 \\
\hline & & E 10656.896 & S. sitiens & 11 & 8,39 \\
\hline & & & S. indicus & 8 & 6,10 \\
\hline & & & S. bengalensis & 4 & 3,05 \\
\hline \multirow{3}{*}{6} & \multirow{3}{*}{ Bina Warga } & S 642.427 & S. calcitrans & 135 & 93,75 \\
\hline & & E 10656.599 & S. sitiens & 5 & 2,77 \\
\hline & & & S. indicus & 4 & 3,47 \\
\hline \multirow{3}{*}{7} & \multirow{3}{*}{ Tirta Kencana } & S 642.084 & S. calcitrans & 211 & 92,95 \\
\hline & & E 10657.119 & S. sitiens & 9 & 3,97 \\
\hline & & & S. indicus & 7 & 3,08 \\
\hline
\end{tabular}

paling sedikit ditemukan dan hanya ditemukan pada empat peternakan (1,01\%-3,70\%).

Lalat Stomoxys spp memiliki bentuk tubuh yang mirip dengan lalat rumah Musca domestica yang membedakan hanyalah tipe mulut lalat tersebut. $S$. calcitrans mempunyai ciri-ciri titik bulat pada tergit 3 dan 4 abdomen pada bagian lateral, toraks terdapat 4 vittae longitudinal, bentuk proboscis merupakan tipe penghisap darah, venasi sayap $\mathrm{m} 1+2$ berbentuk melengkung ke atas, kaki memiliki warna hitam pucat, pada bagian basal kaki $1 / 3$ tibia berwarna kuning pucat, dan pada bagian kaki ke-3 terdapat bristle dekat bagian tengah dari anteroventral.

Morfologi S. sitiens yang spesifik adalah bentuk proboscis tipe pengisap darah, terdapat titik bulat pada abdomen berbentuk memanjang oval pada tergit bagian 3 dan 4, dan pada permukaan ventral femur kaki belakang terdapat rambut yang relatif pendek.

Ciri khusus S. indicus adalah memiliki ukuran tubuh yang lebih kecil dibandingkan dengan spesies lainnya, yaitu $4,5 \mathrm{~mm}$, proboscis tipe mengisap darah dan memiliki titik bulat berupa pita hitam memanjang dan melengkung pada tergit abdomen 3 dan 4 , venasi sayap $\mathrm{m} 1+2$ sedikit melengkung ke atas, tibia dan tarsi kuning pucat.
S. bengalensis memiliki titik hitam memanjang yang sama seperti $S$. indicus, hanya saja ukuran tubuh $S$. bengalensis lebih besar daripada tiga spesies Stomoxys lainnya, yaitu 6,0-7,0 mm, antena kuning kecokelatan, dan pada femur kaki belakang terdapat rambut yang relatif panjang.

Lalat Stomoxys sangat umum dijumpai pada peternakan sapi perah karena sistem pembuangan limbah kotoran ternak hanya ditumpuk pada satu tempat, dan penumpukan kotoran ini telah bercampur dengan urin dan sisa makanan atau rumput merupakan habitat yang tepat untuk perkembangbiakan lalat kandang (Hadi \& Koesharto, 2006). Keempat spesies lalat kandang yang di-temukan pada setiap kandang memiliki ciri-ciri yang berbeda, dan perbedaan paling nyata terdapat pada bagian abdomen lalat. Pentingnya mengetahui ciri-ciri dan karakter setiap spesies lalat ini adalah untuk mengetahui spesies mana yang lebih dominan pada setiap peternakan sapi perah.

Ragam jenis lalat Stomoxys spp berbeda pada setiap wilayah. Amico et al. (1996) melaporkan di Afrika Tengah terdapat jenis Stomoxys yang berbeda, yaitu Stomoxys nigra, S. taeniata, S. sitiens, dan S. omega. Changbunjong et al. (2012) melaporkan di 18 lokasi penelitian yang terdiri atas beberapa kebun 
Tabel 2 Kelimpahan nisbi, frekuensi spesies, dan dominasi spesies lalat terbanyak pada tujuh peternakan sapi perah di Kabupaten Bogor

\begin{tabular}{|c|c|c|c|c|}
\hline Peternakan & Jenis Lalat & Kelimpahan nisbi (\%) & Frekuensi & Dominasi spesies \\
\hline \multirow{3}{*}{ Baru Sirem } & S. calcitrans & 92,59 & 0,56 & 51,58 \\
\hline & S. indicus & 3,70 & 0,03 & 0,11 \\
\hline & S. bengalensis & 3,70 & 0,03 & 0,11 \\
\hline \multirow{3}{*}{ Tirta Kencana } & S. calcitrans & 92,95 & 0,84 & 78,08 \\
\hline & S. sitiens & 3,97 & 0,08 & 0,32 \\
\hline & S. indicus & 3,08 & 0,17 & 0,53 \\
\hline \multirow{3}{*}{ Jaya Mandiri } & S. calcitrans & 93,18 & 0,78 & 72,69 \\
\hline & S. sitiens & 4,54 & 0,08 & 0,37 \\
\hline & S. indicus & 2,27 & 0,08 & 0,19 \\
\hline \multirow{4}{*}{ Mekar Jaya } & S. calcitrans & 89,39 & 0,72 & 64,37 \\
\hline & S. sitiens & 6,06 & 0,13 & 0,79 \\
\hline & S. indicus & 3,53 & 0,17 & 0,57 \\
\hline & S. bengalensis & 1,01 & 0,05 & 0,05 \\
\hline \multirow{4}{*}{ Tegal Mandiri } & S. calcitrans & 82,44 & 0,61 & 50,29 \\
\hline & S. sitiens & 8,39 & 0,13 & 1,10 \\
\hline & S. indicus & 6,10 & 0,22 & 1,34 \\
\hline & S. bengalensis & 3,05 & 0,08 & 0,24 \\
\hline \multirow{3}{*}{ Bina Warga } & S. calcitrans & 93,75 & 0,72 & 67,5 \\
\hline & S. sitiens & 2,77 & 0,28 & 0,78 \\
\hline & S. indicus & 3,47 & 0,20 & 0,70 \\
\hline \multirow{4}{*}{ Baru Tegal } & S. calcitrans & 82,57 & 0,61 & 54,50 \\
\hline & S. sitiens & 6,06 & 0,08 & 0,52 \\
\hline & S. indicus & 9,09 & 0,17 & 0,70 \\
\hline & S. bengalensis & 2,27 & 0,06 & 0,10 \\
\hline
\end{tabular}

binatang, taman konservasi nasional, dan peternakan sapi di Thailand mendapatkan empat spesies, yaitu Stomoxys, S. calcitrans, S. sitiens, S. Indicus, dan S. pulla.

Sementara itu, Kaewrayup et al. (2012) melaporkan penelitian yang dilakukan di Provinsi Nakhon Ratchasima, Thailand, mendapatkan keragaman jenis yang berbeda, yaitu S.calcitrans, S. sitiens, S. Indicus, dan S. urruma. Selanjutnya, Changbunjong et al. (2013) melakukan penelitian lagi di Taman Nasional Khao Yai di Thailand dan mendapatkan keragaman jenis yang berbeda lagi, yaitu S.calcitrans, S. sitiens, S. Uruma, dan S. pulla. Kelimpahan Nisbi, Frekuensi, dan Angka Dominasi
Lalat

Kelimpahan nisbi dan angka dominasi 4 spesies lalat Stomoxys spp yang tertangkap dengan menggunakan vavoua trap dengan jumlah pada setiap lokasi peternakan menunjukkan hasil yang bervariasi dan dapat dilihat pada Tabel 2. Pada setiap peternakan, kelimpahan nisbi tertinggi adalah S.calcitrans. Kelimpahan nisbi tertinggi terdapat pada perternakan Bina Warga (93,75\%), sedangkan kelimpahan nisbi terendah $\mathrm{S}$. calcitrans terdapat pada peternakan Tegal Mandiri $(82,44 \%)$. Tingginya kelimpahan nisbi pada peternakan Bina Warga dikarenakan pengelolaan limbah kandang dan sanitasi kandang yang kurang baik dibandingkan dengan peternakan yang lainnya. Peternak yang selalu menumpuk feses sapi di seputaran kandang menjadikan indikator yang potensial untuk peningkatan populasi lalat Stomoxys spp di peternakan tersebut. S. indicus memiliki kelimpahan nisbi tertinggi pada peternakan Baru Tegal (9,09\%) dan kelimpahan nisbi terendahnya terdapat pada peternakan Jaya Mandiri (2,27\%). S. sitiens yang tertangkap pada enam peternakan memiliki kelimpahan nisbi tertinggi pada peternakan Tegal Mandiri (8,39\%), sedangkan kelimpahan nisbi terendah terdapat pada peternakan Bina Warga $(2,77)$. S. bengalensis merupakan spesies yang paling sedikit tertangkap dan hanya ditemukan di empat peternakan, dan kelimpahan nisbi tertinggi terdapat pada peternakan Baru Sirem (3,70\%), sedangkan kelimpahan nisbi terendah terdapat pada peternakan Mekar Jaya (1,01\%).

Hasil ini sejalan dengan penelitian yang dilakukan oleh Masmeatathip et al. (2006) di Thailand bagian tengah dengan menggunakan perangkap vavoa trap, dari empat spesies yang tertangkap, $\mathrm{S}$. calcitrans merupakan spesies yang tertinggi. 
Changbunjong et al. (2012) juga menyatakan dalam hasil penelitiannya bahwa $S$. calcitrans juga mendominasi spesies dengan jumlah 1.546 dari total 3.314 lalat yang tertangkap yang terdiri atas delapan spesies.

Masmeatathip et al. (2006) melaporkan bahwa S. calcitrans menyebar secara kosmopolitan dan bisa menyerang lebih dari 30 spesies inang yang berbeda baik itu mamalia, unggas, reptil, dan beberapa hewan amfibia. Jumlah S. calcitrans yang cenderung tinggi pada setiap peternakan kemungkinan terjadi karena kepadatan inang yang terlalu tinggi serta didukung oleh keberadaan tempat perkembangbiakan, seperti tumpukan manur sapi di sekeliling kandang sehingga mempermudah lalat ini untuk berkembang (Changbunjong et al., 2012).

\section{Aktivitas Mengisap Darah Lalat Stomoxys spp}

Aktivitas mengisap darah lalat Stomoxys spp dengan waktu yang sama pada setiap bulannya disajikan pada Gambar 1. Jumlah lalat yang mengisap darah diukur dengan menghitung jumlah lalat yang hinggap pada bagian tubuh sapi dengan menggunakan counter.

Gambar 1 menunjukkan lalat Stomoxys spp ini aktif mengisap darah sepanjang hari mulai dari pukul 06.00 sampai dengan pukul 18.00. Aktivitas ini terlihat berbeda-beda pada setiap waktu pengamatan. Akan tetapi, secara umum Stomoxys spp pada setiap peternakan memiliki pola aktivitas yang sama pada setiap waktu pegamatan. Di pagi hari, aktivitas terlihat mulai terjadi pada pukul 06.0007.00 dengan jumlah rata-rata lalat per bulan per peternakan sebanyak 95,91 ekor, dan pada pukul
07.00-08.00 jumlah meningkat menjadi 115,87 lalat per bulan per peternakan dan terus mengalami peningkatan tajam pada jam berikutnya. Pada siang hari saat cuaca mulai panas, aktivitas mulai meningkat pada pukul 12.00 dengan jumlah 125,24 lalat per bulan per peternakan. Puncak aktivitas mengisap darah terjadi pada pukul 16.00 dengan jumlah 144 lalat per bulan per peternakan dan pada waktu selanjutnya menurun menjadi 111,6 lalat per bulan per peternakan.

Aktivitas mengisap darah lalat kandang aktif sepanjang hari, dan memungkinkan akan dapat terjadinya perpindahan patogen penyakit dari satu sapi ke sapi lainnya dengan cepat. Selain itu, gigitan lalat kandang ini dapat menyebabkan sapi gelisah dikarenakan menahan rasa sakit atas gigitan lalat ini dan akan berdampak pada penurunan bobot badan sapi dan produksi susu (Campbell et al., 2001; De castro et al., 2007) dan berdampak pada kerugian para petani sapi perah.

Phasuk et al. (2013) juga melaporkan bahwa pada musim panas, puncak aktivitas Stomoxys spp terjadi pada pagi menjelang siang hari dari pukul 10.00 dan mencapai puncak aktivitas pada pukul 15.00. Pada musim hujan juga memiliki pola aktivitas yang sama, yaitu mencapai puncak aktivitas pada siang hari. Masmeatathip et al. (2006) melaporkan pada peternakan sapi potong menunjukkan aktivitas Stomoxys spp aktif sepanjang hari dan mencapai puncak aktivitas pada pukul 14.00-16.00. Hal serupa juga terlihat pada peternakan sapi perah pada penelitian ini di Kabupaten Bogor dengan puncak aktivitas mengisap darah pada pukul 14.00-16.00.

Satu di antara faktor penyebab peningkatan aktivitas mengisap darah pada tubuh sapi di siang hari

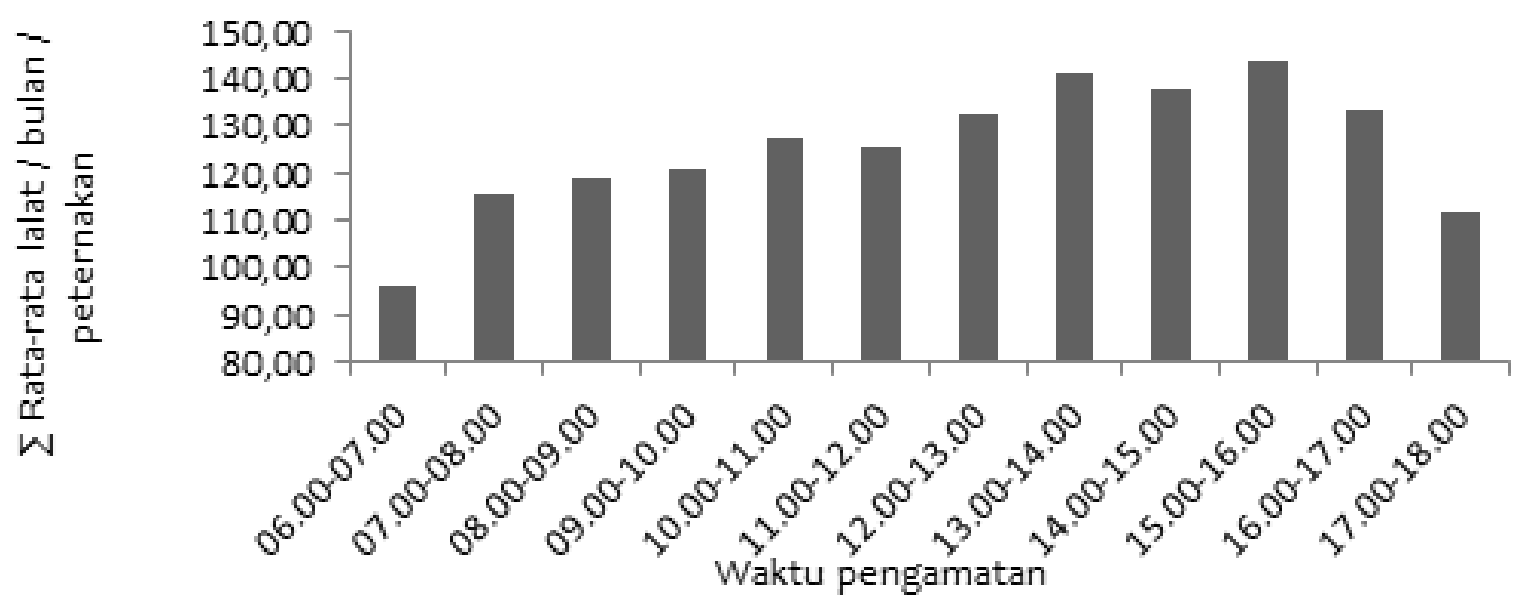

Gambar 1 Aktivitas mengisap darah lalat Stomoxys spp pada tubuh sapi di tujuh peternakan sapi perah di Kabupaten Bogor pada periode April hingga Juni 2015 
adalah tidak adanya pekerja yang datang ke dalam kandang untuk memberikan pakan atau memerah susu. Lalat Stomoxys spp akan terganggu dengan kedatangan para peternak sehingga lalat-lalat akan terbang keluar kandang dan akan berada di sekitar kandang.

Tidak adanya gangguan bagi lalat menyebabkan Stomoxys spp selalu aktif sepanjang hari. Gangguan hanya didapat dari sapi perah yang kesakitan menahan gigitan lalat kandang, seperti tandukan kepala, kibasan ekor, kedutan kulit, dan hentakan kaki. Mullens et al. (2006) menyatakan bahwa hentakan kaki dan kibasan ekor dari sapi dapat mengganggu aktivitas mengisap darah lalat dan mampu menurunkan infestasi lalat kandang.

Perbedaan cuaca dan sanitasi kandang juga mempengaruhi aktivitas lalat mengisap darah. Changbunjong et al. (2013) melaporkan bahwa aktivitas Stomoxys spp di Thailand terjadi mulai siang hingga sore hari dan mulai menurun pada sore menjelang malam.

\section{Hubungan Indeks Curah Hujan dengan Aktivitas Mengisap Darah}

Keadaan curah hujan di dua kecamatan yang menjadi lokasi penelitian untuk tujuh peternakan dari April hingga Juni 2015 sangat bervariasi. Curah hujan tertinggi terjadi pada bulan April yang mencapai $336 \mathrm{~mm}$ dan menurun pada bulan Mei dengan jumlah hari hujan sebanyak 21 hari dengan Indeks Curah Hujan (ICH) 235,20 mm/hari. Pada bulan Mei, curah hujan menurun $310 \mathrm{~mm}$ dengan jumlah hari hujan 14 hari dengan ICH 124,00 mm/hari, dan pada bulan Juni curah hujan menurun sangat drastis, yaitu $15 \mathrm{~mm}$ dengan jumlah hari hujan lima hari dengan $\mathrm{ICH} 2,50 \mathrm{~m} /$ hari.

Berdasarkan hasil uji korelasi statistik menunjukkan adanya korelasi yang sangat kuat tetapi tidak signifikan $(R=-0,922$ dan nilai $p=0.253)$ dengan arah korelasi yang tidak searah antara curah hujan dan aktivitas mengisap darah (Tabel 3). Semakin tinggi curah hujan maka aktivitas mengisap darah akan menurun, dan sebaliknya semakin rendah curah hujan maka aktivitas mengisap darah akan akan semakin meningkat. Tidak signifikannya korelasi tersebut juga dikarenakan terlalu singkatnya waktu penelitian yang dikorelasikan sehingga hujan tidak berpengaruh pada aktivitas lalat Stomoxys spp. Faktor lain, seperti aktivitas peternak yang masuk ke dalam kandang untuk memberi makan dan memerah susu, serta keadaan sanitasi kandang yang berbeda juga mempengaruhi aktivitas mengisap darah.

Keadaan curah hujan yang sangat fluktuatif di daerah penelitian mengakibatkan peningkatan aktivitas mengisap darah lalat Stomoxys spp. Barry \& Campbell (1985) di Mexico melaporkan bahwa suhu dapat mempengaruhi aktivitas harian lalat kandang. Vazquez et al. (2004) juga melaporkan tidak ada korelasi yang signifikan antara curah hujan dengan populasi Stomoxys, dan dilaporkan juga bahwa temperatur, curah hujan, dan kelembapan menjadi faktor utama dalam peningkatan dan penurunan populasi lalat kandang. Lokasi dengan suhu yang mendukung dan keadaan sanitasi kandang yang buruk dapat menjadi faktor yang sangat potensial untuk terjadinya peningkatan populasi lalat kandang.

Penelitian mengenai ragam jenis lalat Stomoxys di tujuh peternakan di Kabupaten Bogor terdiri atas S. calcitrans, S. sitiens,S. Indicus, dan S. bengalensis. Jenis yang memiliki kelimpahan nisbi tertinggi adalah S. calcitrans (93,75\%) di peternakan Bina Warga dan terendah di peternakan Tegal Mandiri $(82,44 \%)$. S. indicus dengan kelimpahan nisbi tertinggi (9,09\%) ditemukan di peternakan Baru Tegal dan terendah (2,27\%) di peternakan Jaya Mandiri. S. sitiens ditemukan dengan kelimpahan nisbi tertinggi di peternakan Tegal Mandiri (8,39\%) dan terendah $(2,77 \%)$ di peternakan Bina Warga, sedangkan S. bengalensis memiliki kelimpahan nisbi tertinggi di peternakan Baru Sirem (3,70\%) dan terendah (1,01\%) ditemukan di peternakan Mekar Jaya.

Aktivitas mengisap darah lalat Stomoxys spp sangat berfluktuasi pada setiap jam pengamatan. Lalat Stomoxys spp mulai aktif muncul pada pukul 06.00-07.00, kemudian semakin meningkat pada setiap jam dan puncak aktivitas mengisap darah terjadi pada pukul 15.00-16.00. Hasil uji korelasi Pearson

Tabel 3 Hubungan indeks curah hujan dengan aktivitas mengisap darah lalat Stomoxys spp di tujuh peternakan sapi perah di Kabupaten Bogor

\begin{tabular}{ccccc}
\hline Bulan & Lalat & ICH & $\mathrm{R}$ & $\mathrm{P}$ \\
\hline April & 1045 & 235,20 & & \\
Mei & 1055 & 124,00 & $-0,922$ & 0,253 \\
Juni & 1138 & 2,50 & & \\
\hline
\end{tabular}


antara Indeks Curah Hujan dengan aktivitas mengisap darah lalat Stomoxys spp menunjukkan korelasi yang sangat kuat tetapi tidak signifikan $(R=-0,922)$ dan nilai $(p=0,253>0,05)$ dikarenakan pendeknya masa penelitian (tiga bulan).

Ragam jenis lalat Stomoxys di tujuh peternakan di Kabupaten Bogor terdiri atas S. calcitrans, S. sitiens, S. Indicus, dan S. bengalensis. Jenis yang memiliki kelimpahan nisbi tertinggi adalah $S$. calcitrans $(93,75 \%)$ di peternakan Bina Warga dan terendah di peternakan Tegal Mandiri $(82,44 \%)$. S. indicus dengan kelimpahan nisbi tertinggi (9,09\%) ditemukan di peternakan Baru Tegal dan terendah $(2,27 \%)$ di peternakan Jaya Mandiri. S. sitiens ditemukan dengan kelimpahan nisbi tertinggi di peternakan Tegal Mandiri (8,39\%) dan terendah $(2,77 \%)$ di peternakan Bina Warga, sedangkan S. bengalensis memiliki kelimpahan nisbi tertinggi di peternakan Baru Sirem (3,70\%) dan terendah (1,01\%) ditemukan di peternakan Mekar Jaya. Aktivitas mengisap darah lalat Stomoxys spp sangat berfluktuasi pada setiap jam pengamatan. Lalat Stomoxys spp mulai aktif muncul pada pukul 06.0007.00, kemudian semakin meningkat pada setiap jam dan puncak aktivitas mengisap darah terjadi pada pukul 15.00-16.00. Hasil uji korelasi Pearson antara Indeks Curah Hujan dengan aktivitas mengisap darah lalat Stomoxys spp menunjukkan korelasi yang sangat kuat tetapi tidak signifikan ( $R=-0.922$ dan nilai $p=0,253>0,05)$ dikarenakan pendeknya masa penelitian (tiga bulan).

\section{UCAPAN TERIMA KASIH}

Penulis mengucapkan terima kasih kepada semua staf Program studi Parasitologi dan Entomologi Kesehatan, Kepala Dinas Peternakan Kabupaten Bogor atas izin, pegawai di UPT tujuh Ciawi dan semua ketua kelompok ternak yang tergabung dalam KUD Giri Tani atas bantuan dan kerja samanya selama pelaksanaan penelitian ini berlangsung, dan semua pihak yang telah membantu sehingga penelitian ini dapat berjalan lancar.

\footnotetext{
"Penulis menyatakan tidak ada konflik kepentingan dengan pihak-pihak terkait dalam penelitian ini".
}

\section{DAFTAR PUSTAKA}

Amico FD, Gouteux JP, Gall LF, Cuisance D. 1996. Are stable flies (Diptera: Stomoxyinae) vectors of Trypanosoma vivax in Central African Republic?. Veterinary Research. 27: 161-170.

Batista ZR, Leite RC, Oliveira PR, Lopes CML, Borges LMF. 2005. Population dynamics of Stomoxys calcitrans (Linneaus) (Diptera:Muscidae) in three biocenosis, minas gerais, Brazil. Veterinery Parasitology. $130: 343-346$.

Berry LL, Campbell JB. 1985. Time and weather effect on daily feeding pattern of Stable Flies (Diptera:Muscidae). Environment Entomology. 14: $336-342$.

Campbell JB, Skoda SR, Berkebile D, Boxler DJ, Tomas GD. 2001. Wild Florida house flies (Diptera: Muscidae) on weight gains of grazing yearling cattle. Journal Economic Entomology. 94(3): 780-783.

Changbunjong T, Weluwanarak T, Ratanakorn $\mathrm{P}$, Maneeon P, Ganpanakngan M, Apiwathnasorn C, Sungvornyothin $S$, Sriwichai $P$, Sumruayphol $S$, Ruangsittichai J. 2012. Distribution and abudance of Stomoxyini flies (Diptera:Muscidae) in Thailand. Journal Tropical Medecine Publict Health. 43 (6): $1400-1410$.

Changbunjong T, Weluwanarak T, Sedwisai $P$, Chamsai P. 2013. Stomoxyini fly fauna of the Khao Yai National Park, Thailand. Asian Pacific Journal Troical Disease. 3 (5): 348 - 351.

De Castro BG, De Souza MMS, Bittencourt AJ. (2007). Aerobic bacterial microbiota in Stomoxys calcitrans preliminary studies in Brazil. Brasil Journal Veterinery Parasitology. 16 (40): 193-19.

Gilles J, David JF, Duvallet G. 2005. Temperatur effect on development and survival of two stable flies, Stomoxys calcitrans and Stomoxys niger niger (Diptera : Muscidae ), in La Reunion Island. Journal Medical Entomology. 42 (3): $260-265$.

Hadi UK, Koesharto F. 2006. Hama Permukiman Indonesia. Pengenalan, Biologi, dan Pengendalian. Unit Kajian Pengendalian Hama Permukiman. Fakultas Kedokteran Hewan Institut Pertanian Bogor (ID) : IPB Press. p58-59.

Keawrayup S, Duvallet G, Sukonthabhirom S, Chareonviriyaphap T. 2012. Diversity of Stomoxys spp (Diptera : Muscidae) and diurnal variation of activity of Stomoxys indicus, and S. calcitrans in a farm in Wang Nam Khiao District, Nakhon Ratchasima province, Thailand. Parasite. 19:259-265. 
Masmeatathip R, Ketavan C, Duvallet G. 2006 Morphological studies of Stomoxys spp. (Diptera: Muscidae) in Central Thailand. Kasetsart Journal (National Scientic). 40: 872-881.

Masmeatathip R, Gilles J, Ketavan C, Duvallet G. 2006. First survey of seasonal abudance and daily activity of Stomoxys spp (diptera : muscidae) in Kamphaengsaen Campus, Nakoornpathom Province, Thailand. Parasite. 13: 245- 250.

Mullens BA, Lii KS, Meyer JA, Peterson NG, Szijj CE. 2006. Behavioral responses of dairy cattle to the stabel fly, Stomoxys calcitrans, in an open Field environment. Medical Veteriner Entomology. 20: $122-137$.

Phasuk J, Prabaripai A, Chareonviriyaphap T. 2013. Seasonality and daily flight activity of stable flies (Diptera : Muscidae) on dairy farms in Saraburi Province, Thailand. Parasite. 20 (17): 1-7.

Rodríguez NF, Junco MTJ, Martin MG, Gutierrz C. 2014. Stomoxys calcitrans as possible vector of Trypanosoma evansi among camels in an affected area of the Canary Islands, Spain. Revista da Sociedade Brasileira de Medicina Tropical. 47 (4):510-512.

Sukanto IP, Politedy FL, Solihat, Dachlan $M$, Wardhana, Satria E. 2000. Peran diptera hemato- fagus sebagai vektor Trypanosoma evansi. Prosiding Seminar Nasional Peternakan dan Veteriner 481-487.

Sumba AL, Mihok S, Oyieke FA. 1998. Mechanical transmission of Trypanosoma evansi and $T$. congolense by Stomoxys niger and S. taeniatus in a laboratory Mouse Model. Medical Veteriner Entomology. 12: 417-422.

Tarmudji. 2003. Beberapa penyakit penting pada kerbau di Indonesia. Wartazoa. 13(4): 160-170.

Taylor DB. Moon RD, Mark DR. 2012. Economic impact of stable flies (Diptera: Muscidae) on dairy and beef cattle production. Journal Medical Entomology. 49 (1): 198-209.

Tumrasvin W, Shinonaga S. 1978. Studies on medically important flies in Thailand. 32 species belonging to subfamilies Muscinae and Stomoxyinae including the taxonomy keys (Diptera: Muscidae). Bull Tokyo Med Dent Univ. 25: 201-270.

Vazquez CC, Mendoza IV, Parra MR, Vazquez ZG. 2004. Influence of temperature, humidity and rainfall on field population trend of Stomoxys calcitrans (Diptera : Muscidae) in a semiarid climate in Mexico. Parasitolo Latinoam. 59: 99 - 103. 